\title{
Molecular characterization of enterohemorrhagic Escherichia coli isolated from diarrhea samples from human, livestock, and ground beef in North Jordan
}

\author{
Yaser H. Tarazi ${ }^{1}$, Saeb N. El-Sukhon ${ }^{1}$ (D), Zuhair Bani Ismail² ${ }^{\mathbb{D}}$ and Amani A. Almestarehieh ${ }^{1}$ (D)
}

\author{
1. Department of Basic Medical Veterinary Sciences, Faculty of Veterinary Medicine, Jordan University of Science \\ and Technology, Irbid, Jordan; 2. Department of Veterinary Clinical Sciences, Faculty of Veterinary Medicine, Jordan \\ University of Science and Technology, Irbid, Jordan. \\ Corresponding author: Yaser H. Tarazi, e-mail: tarazi@just.edu.jo \\ Co-authors: SNE: sukhon@just.edu.jo, ZBI: zuhair72@just.edu.jo, AAA: aammaa1988@hotmail.com
} Received: 18-05-2021, Accepted: 30-08-2021, Published online: 30-10-2021

doi: www.doi.org/10.14202/vetworld.2021.2827-2832 How to cite this article: Tarazi YH, El-Sukhon SN, Ismail ZB, Almestarehieh AA (2021) Molecular characterization of enterohemorrhagic Escherichia coli isolated from diarrhea samples from human, livestock, and ground beef in North Jordan, Veterinary World, 14(10): 2827-2832.

\begin{abstract}
Background and Aim: Enterohemorrhagic Escherichia coli (EHEC) is an important foodborne pathogen with worldwide distribution. Data regarding its presence, distribution, virulence, and antimicrobial susceptibility among various animal species and humans in Jordan are lacking. Therefore, the objectives of this study were to isolate and characterize EHEC from human and animal diarrhea fecal samples and ground beef samples.

Materials and Methods: A total of 100 and 270 diarrhea fecal samples from humans and animals, respectively, were collected. In addition, 40 ground beef meat samples were collected from retail markets. EHEC was positively identified by detecting Shiga toxins (stxl and stx2) genes using multiplex polymerase chain reaction (PCR). Antimicrobial susceptibility patterns were determined using the disk diffusion test. Beta-lactamase production was detected using the double disk diffusion test and the extended-spectrum beta-lactamases (ESBLs) were identified by detection of bla $a_{T E M}$, bla $a_{S H V}$, and $O X A-1$ genes using multiplex PCR. Pulsed-field gel electrophoresis (PFGE) was used to investigate the relatedness of EHEC isolates from different sources.

Results: Out of 410 samples, $194 \mathrm{E}$. coli isolates were positively identified, of which 57 isolates (29\%) were classified as EHEC. Thirty-five (61\%) of EHEC isolates were serotyped as O157 (19: O157:H7 and 16: O157:NM). The stx1 gene was detected only among the sheep and goats isolates at a rate of $7.6 \%$ and $5.2 \%$, respectively, while the stx2 gene was detected in only one ground beef meat sample. EHEC isolates showed high resistance patterns against amoxicillin, gentamycin, cephalexin, and doxycycline. Twenty-four out of 32 EHEC isolates were determined as ESBL producers, among which 14 isolates expressed the bla $a_{S H V}$ gene and 19 isolates expressed the bla $a_{T E M}$ while four expressed both genes. PFGE analysis revealed two clusters with high similarity (92\%) originated from ground beef meat and cattle fecal samples. No similarities were found between human and animal $E$. coli isolates.
\end{abstract}

Conclusion: Results of this study indicate widespread ESBL EHEC among humans, animals, and ground beef meat samples. These results represent an important alarm that requires the implementation of appropriate preventative measures by both human and animal health sectors to prevent the transmission of this important foodborne pathogen.

Keywords: animal health, Enterobacteriaceae, foodborne pathogens, public health.

\section{Introduction}

Escherichia coli is a Gram-negative bacillus of the family Enterobacteriaceae [1,2]. Although E. coli bacteria are normal inhabitants of the gastrointestinal tract of both humans and animals, pathogenic strains are capable of causing important and potentially fatal diseases [1,2].

In humans, enterohemorrhagic E. coli (EHEC) is considered important zoonotic bacteria causing severe bloody diarrhea, hemorrhagic colitis,

Copyright: Tarazi, et al. Open Access. This article is distributed under the terms of the Creative Commons Attribution 4.0 International License (http://creativecommons.org/licenses/by/4.0/), which permits unrestricted use, distribution, and reproduction in any medium, provided you give appropriate credit to the original author(s) and the source, provide a link to the Creative Commons license, and indicate if changes were made. The Creative Commons Public Domain Dedication waiver (http://creativecommons.org/ publicdomain/zero/1.0/) applies to the data made available in this article, unless otherwise stated. hemolytic-uremic syndrome, and thrombotic thrombocytopenic purpura [1-5]. In cattle and sheep, several pathogenic E. coli are the cause of neonatal calf diarrhea and sepsis, including enterotoxigenic (ETEC), enteropathogenic (EPEC), shigatoxigenic (STEC), enterohemorrhagic (EHEC), enteroinvasive (EIEC), enteroaggregative (EAEC), and enteroadherent E. coli (EAdEC) strains [6-10].

Several outbreaks of foodborne illnesses around the world have been traced back to the consumption of poultry and ground meat, dairy products, and fresh vegetables contaminated with E. coli O157:H7 [1-3]. This extremely pathogenic strain of $E$. coli is characterized by several virulence factors, including biofilm formation and production of potent toxins, including Shiga toxins, intimin, and enterohemolysin [1-11].

In Jordan, there is a paucity of information regarding the presence, distribution, virulence, and 
antimicrobial susceptibility of EHEC among various animal species and humans. Therefore, the objective of study was to isolate and characterize EHEC from human and animals' diarrhea fecal samples, poultry litter, and ground beef samples.

\section{Materials and Methods}

\section{Ethical approval and informed consent}

The study was approved by the Institutional Animal Use and Care Committee of Jordan University of Science and Technology. Informed written and signed consents were obtained from farm owners and human patients before sample collection was carried out.

\section{Study period and location}

The study was carried out from April 2014 and June 2015 at the Research Microbiology Laboratory, Faculty of Veterinary Medicine, Jordan University of Science and Technology, Jordan.

\section{Sample collection}

\section{Human samples}

A total of 100 fecal swab samples were collected from human patients affected with gastroenteritis characterized by diarrhea and abdominal pain. Patients were of various ages ranging from 15 to 75 years who undergone medical evaluation for acute gastroenteritis in two local medical centers located in North Jordan. Sterile swabs (FecalSwab; Copan, USA) were used to collect fecal samples in an aseptic manner by the patient who was instructed to wear disposable gloves during sample collection. Samples were transported to the laboratory within 2-4 $\mathrm{h}$ after collection and were cultured immediately.

\section{Animal fecal samples}

A total of 270 fecal samples were collected from cattle $(n=100)$, sheep $(n=35)$, goats $(n=35)$, and broiler chicken litter $(n=100)$. Samples were collected aseptically using a gloved hand directly from the rectum (cattle, sheep, and goats) and from fresh poultry litter. Samples were obtained from animals suffering from acute gastroenteritis characterized by diarrhea. Animals belonged to several farms located in Northern and Middle regions of Jordan. Samples were placed in sterile plastic fecal containers with screw caps and transported to the laboratory within 2-4 h after collection for immediate culture.

\section{Ground meat samples}

A total of 40 ground beef meat samples were collected aseptically from local retail markets. Approximately $100 \mathrm{~g}$ of ground meat was placed in sterile containers with screw cap and transported to the laboratory within $2-4 \mathrm{~h}$ after collection for immediate culture.

\section{Bacterial culture and identification}

A reference strain of EHEC O157:H7 (ATCC 700728) was obtained from Jordan Food and Drug Administration (Amman, Jordan) and was used as a positive control in the study. Bacterial culture was performed according to previously published protocols $[3,12]$. Briefly, fecal swabs were inoculated into $9 \mathrm{~mL}$ of Mueller-Hinton broth (Oxoid, UK) and incubated at $37^{\circ} \mathrm{C}$ for $24 \mathrm{~h}$. Then, a loopful was streaked on MacConkey agar medium (Oxoid) and on eosin methylene blue (Oxoid) and incubated overnight at $37^{\circ} \mathrm{C}$. Colonies of E. coli were identified by biochemical reactions using IMViC test (Tulip Diagnostics, India).

\section{Identification and serotyping of $E$. coli 0157:H7}

$E$. coli colonies were inoculated on sorbitol MacConkey agar (Oxoid) and incubated for 18-24 h at $37^{\circ} \mathrm{C}$. The isolates that showed the inability to ferment sorbitol with colorless or pale color colonies were predicted to be O157:H7. Suspected O157:H7 isolates were further serotyped using microtiter plate agglutination against nine specific $\mathrm{O}$-antisera, including O157, O8, O26, O45, O121, O145, O113, O103, and O111 (Statens Serum Institute, Copenhagen, Denmark).

\section{DNA extraction}

DNA was extracted using cell lysis method [13]. Briefly, $40 \mu \mathrm{L}$ of SCLB $(1 \mathrm{~mL}$ of $1 \times$ concentration of Tris-Borate-EDTA [TBE] buffer [Bio Basic, Canada] plus $10 \mu \mathrm{L}$ of proteinase $\mathrm{K}[5 \mathrm{mg} / \mathrm{mL}]$ ) were added to individual sterile polymerase chain reaction (PCR) tubes. A single colony of $E$. coli from MHA was added as DNA template. Amplification was carried out using in BioRad MyCycler ${ }^{\mathrm{TM}}$ (Bio-Rad, California, USA) at $80^{\circ} \mathrm{C}$ for $10 \mathrm{~min}$ followed by one cycle at $55^{\circ} \mathrm{C}$ for $10 \mathrm{~min}$. Then, $80 \mu \mathrm{L}$ of $\mathrm{ddH}_{2} \mathrm{O}$ was added, centrifuged at $7000 \mathrm{rpm}$ for $2 \mathrm{~min}$, and finally, the extracted templates were stored at $4^{\circ} \mathrm{C}$ until used.

\section{Molecular confirmation of $E$. coli}

E. coli was confirmed by PCR using universal E. coli Eco-1 and Eco-2 primers (Table-1) [12-14]. The reference strain ATCC 22925 and normal saline were used as positive and negative control, respectively. The PCR reaction mixture was prepared from $2 \mu \mathrm{L}$ of DNA template, $2 \mu \mathrm{L}$ of $\mathrm{MgCl}_{2}(25$ $\left.\mathrm{Mm} \mathrm{MgCl}_{2}, \mathrm{KAPA}\right), 10 \mu \mathrm{L}$ of $2 \times$ PCR master mix solution (Intron, South Korea), $1 \mu \mathrm{L}$ (10 pmoles) of each primer, and $4 \mu \mathrm{L}$ of nuclease-free water (IDT, Coralville, Iowa, USA) in a final volume of $20 \mu$ L. Amplification was carried out using BioRad MyCycler ${ }^{\mathrm{TM}}$ (Bio-Rad), at $94^{\circ} \mathrm{C}$ for $3 \mathrm{~min}$, followed by 35 cycles of $94^{\circ} \mathrm{C}$ for $30 \mathrm{~s}$, annealing at $62^{\circ} \mathrm{C}$ for $1 \mathrm{~min}$, and extension at $72^{\circ} \mathrm{C}$ for $30 \mathrm{~s}$, with a final extension at $72^{\circ} \mathrm{C}$ for $7 \mathrm{~min}$. The products were subjected to electrophoresis on $1 \%$ agarose gels (CSL-AG 100) containing ethidium bromide $(10 \mathrm{mg} / \mathrm{mL}$ solution). Molecular ladder with $100 \mathrm{bp}$ of size was used as a marker (GeneDireX, Taiwan). Agarose gel electrophoresis was performed in $1 \times$ TBE buffer at $100 \mathrm{~V}$ for $35 \mathrm{~min}$ and finally visualized under UV light (Alpha Innotech, USA). 
Table-1: Primer sequence and product size of target genes used to detect Escherichia coli and its virulence factors.

\begin{tabular}{|c|c|c|c|}
\hline Primer sets & Target gene & Primer sequence $5^{\prime}-3^{\prime}$ & Product size (bp) \\
\hline Eco & malB promoter & $\begin{array}{l}\text { F: GACCTCGGTTTAGTTCACAGA } \\
\text { R: CACACGCTGACGCTGACCA }\end{array}$ & 585 \\
\hline Rfb & 0157 & $\begin{array}{l}\text { F: GTGTCCATTTATACGGACATCCATG } \\
\text { R: CCTATAACGTCATGCCAATATTGCC }\end{array}$ & 292 \\
\hline sxt1 & Stx 1 & $\begin{array}{l}\text { F: TGTAACTGGAAAGGTGGAGTATAC } \\
\text { R: GCTATTCTGAGTCAACGAAAAATAAC }\end{array}$ & 210 \\
\hline sxt2 & Stx2 & $\begin{array}{l}\text { F: GTIITCTTCGGTATCCTATTCCG } \\
\text { R: GATGCATCTCTGGTCATTGTATTAC }\end{array}$ & 484 \\
\hline FliCh7 & $H 7$ & $\begin{array}{l}\text { F: GCGCTGTCGAGTTCTATCGAGC } \\
\text { R: CAACGGTGACTTATCGCCATTCC }\end{array}$ & 625 \\
\hline Multi TSO-T & bla $_{T E M}$ & $\begin{array}{l}\text { F: CATTTCCGTGTCGCCCTTATTC } \\
\text { R: CGTTCATCCATAGTTGCCTGAC }\end{array}$ & 800 \\
\hline Multi TSO-S & $b l a_{S H V}$ & $\begin{array}{l}\mathrm{F}: \text { AGCCGCTTGAGCAAATTAAAC } \\
\text { R: ATCCCGCAGATAAATCACCAC }\end{array}$ & 713 \\
\hline Multi TSO-O & $O X A-1$ & $\begin{array}{l}\text { F: GGCACCAGATTCAACTITCAAG } \\
\text { R: GACCCCAAGTITCCTGTAAGTG }\end{array}$ & 564 \\
\hline
\end{tabular}

\section{Detection of stx1, stx2, and 0157:H7 genes}

Shiga toxins 1 and 2, O157 (RfbE), and $H 7$ (Flich7) target genes were detected in isolated E. coli strains using multiplex PCR. The PCR reaction was prepared in $20 \mu \mathrm{L}$ final volume which contained $8.2 \mu \mathrm{L}$ of nuclease-free water, $5 \mu \mathrm{L}$ of the DNA template, $4 \mu \mathrm{L}$ of ready $5 \times$ Hot FIREPol ${ }^{\circledR}$ Blend Master Mix Ready to load [Hot FIREPol ${ }^{\circledR}$ DNA Polymerase, proofreading enzyme, $5 \times$ Blend Master Mix Buffer, $12.5 \mathrm{mM} \mathrm{Mgcl} 2,2 \mathrm{mM}$ dNTPs (Solis Biodyne, Estonia)], and selected primers (Table-1) to a final concentration of $10 \mu \mathrm{M}[7,15]$. The thermocycling conditions were set at initial denaturation of $95^{\circ} \mathrm{C}$ for $15 \mathrm{~min}$, followed by 25 cycles of $94^{\circ} \mathrm{C}$ for $30 \mathrm{~s}$, $65^{\circ} \mathrm{C}$ for $90 \mathrm{~s}, 72^{\circ} \mathrm{C}$ for $90 \mathrm{~s}$, and final extension at $72^{\circ} \mathrm{C}$ for $7 \mathrm{~min}$. Amplified samples were evaluated by $1.2 \%$ agarose gel electrophoresis in $1 \times$ of TBE buffer, ethidium bromide $(0.5 \mu \mathrm{g} / \mathrm{mL})$ staining and visualized under UV illumination [16].

\section{Antimicrobial susceptibility test}

Antimicrobial susceptibility test was performed using the Kirby-Bauer disk diffusion method on MHA according to the recommendations of the Clinical and Laboratory Standard Institute guidelines [17]. Sixteen different antimicrobial agents were used (Bioanalyse, Turkey) including doxycycline (DO $30 \mu \mathrm{g}$ ), amoxicillin (AX $25 \mu \mathrm{g}$ ), gentamicin (CN $10 \mu \mathrm{g}$ ), (ciprofloxacin $5 \mu \mathrm{g}$ ), (levofloxacin $5 \mu \mathrm{g}$ ), (florfenicol $30 \mu \mathrm{g}$ ), (cefepime $30 \mu \mathrm{g}$ ), (aztreonam $30 \mu \mathrm{g}$ ), (imipenem $10 \mu \mathrm{g}$ ), (ceftriaxone $30 \mu \mathrm{g}$ ), (cefoxitin $30 \mu \mathrm{g}$ ), cephalexin (CL $30 \mu \mathrm{g}$ ), (cefuroxime $30 \mu \mathrm{g}$ ), (cefotaxime $30 \mu \mathrm{g}$ ), ceftazidime (CAZ $30 \mu \mathrm{g}$ ), and (trimethoprim/sulfamethoxazole $25 \mu \mathrm{g})$. Antimicrobial susceptibility was reported as a measure of the diameter of the inhibition zone in millimeters after incubation at $37^{\circ} \mathrm{C}$ for $24 \mathrm{~h}$.

\section{Double-disk synergy test (DDST)}

The DDST was used to detect extended-spectrum beta-lactamase (ESBL) genes among EHEC isolates [17]. Briefly, isolates were inoculated on MHA plates. Then, an AX/clavulanic acid disk was placed in the center of the plate. Then, CAZ and ceftizoxime disks were placed at $25 \mathrm{~mm}$ from the center and away from the AX/clavulanic acid disk. The plates were then incubated at $37^{\circ} \mathrm{C}$ for $24 \mathrm{~h}$. An increase of $>5 \mathrm{~mm}$ of the inhibition zone was recorded as a positive result. A reference strain of $E$. coli (ATCC 700728) was used for comparison as a positive control.

\section{Detection of bla ${ }_{T E M}, b_{S H V}$ and OXA-1 genes}

ESBL-positive isolates were used to detect the chromosomal and plasmid-mediated genes, including bla $_{T E M}$, bla $_{S H}$, and $O X A-1[18]$. Briefly, $2 \mu \mathrm{L}$ DNA aliquot was subjected to each multiplex PCR in $20 \mu \mathrm{L}$ reaction mixture containing $10.6 \mu \mathrm{L}$ of nuclease-free water, $3 \mu \mathrm{L}$ of the template, $4 \mu \mathrm{L}$ of ready $5 \times$ Hot FIREPol ${ }^{\circledR}$ Blend Master Mix Ready to load (Hot FIREPol ${ }^{\circledR}$ DNA Polymerase, Proofreading enzyme, $5 \times$ Blend Master Mix Buffer, $12.5 \mathrm{mM} \mathrm{MgCl}$, $2 \mathrm{mM}$ dNTPs), and a variable concentration of specific-group primers (Table-1). Amplifications were carried out as follows: Initial denaturation at $94^{\circ} \mathrm{C}$ for $10 \mathrm{~min}$ followed by 30 cycles of $94^{\circ} \mathrm{C}$ for $40 \mathrm{~s}, 60^{\circ} \mathrm{C}$ for $40 \mathrm{~s}$ and $72^{\circ} \mathrm{C}$ for $1 \mathrm{~min}$, and a final elongation step at $72^{\circ} \mathrm{C}$ for $7 \mathrm{~min}$. Amplified samples were evaluated after running at $100 \mathrm{~V}$ for $1 \mathrm{~h}$ on a $2 \%$ agarose gel containing ethidium bromide $(0.5 \mu \mathrm{g} / \mathrm{mL})$. A $100 \mathrm{bp}$ DNA ladder (BioLabs, USA) was used as a size marker.

\section{Pulse-field gel electrophoresis (PFGE)}

A total of 41 EHEC isolates were used in the PFGE using restriction enzyme digestion with XbaI enzyme (Thermo Fisher, USA) according to previously published protocols [19]. Gel electrophoresis was performed using the Chef Mapper XA PFGE system (Bio-Rad) under the following conditions: Initial switch time: $2.2 \mathrm{~s}$; final switch time: $54.2 \mathrm{~s}$; run time: $18 \mathrm{~h}$; angle: $120^{\circ}$; gradient: $6.0 \mathrm{~V} / \mathrm{cm}$; temperature: $14^{\circ} \mathrm{C}$; and ramping factor: linear. The electrophoresis gels were stained using ethidium bromide and visualized under ultraviolet light. The genotypic relatedness was determined using PFGE DNA fingerprint subtypes. The analysis of the bands was carried out using 
the Dice coefficient and the unweighted pair group method with arithmetic averages clustering methods with an optimization and position tolerance of $1.0 \%$. Analysis of PFGE gel patterns was performed using BioNumerics software version 3.5 (Applied Maths, Belgium).

\section{Results}

A total of $194(47.3 \%)$ E. coli were isolated from 100 (44\%) human, 100 (46\%) cattle, 35 (74\%) sheep, $35(54 \%)$ goats, and $100(39 \%)$ broilers fecal samples and $40(50 \%)$ ground beef meat samples (Table-2).

\section{Serotypes and virulence factors}

Serotypes and virulence genes in EHEC isolated from human, animals' fecal samples, poultry litter, and ground beef samples are presented in Table- 2 . Fifty-seven $(29.4 \%)$ isolates out of 194 were identified as EHEC of which 19 isolates were O157:H7 and 16 were $\mathrm{O} 157: \mathrm{H}$ serotypes. Twenty-two isolates (11\%) were non-O157.

A total of $22(38.5 \%)$ out of 57 isolates belonged to five serotypes $(\mathrm{O} 26, \mathrm{O} 111, \mathrm{O} 113, \mathrm{O} 103$, and $\mathrm{O} 8)$. In human samples, $\mathrm{O} 111, \mathrm{O} 26$, and $\mathrm{O} 113$ serogroups were detected in a total of $8(18.6 \%)$ out of 43 isolates. In cattle samples, only 1 isolate $(2.5 \%)$ was found to be O8. In sheep samples, the O111, O26, and $\mathrm{O} 103$ serogroups were detected in a total of $6(33.3 \%)$ out of 18 isolates. In goat samples, only 1 isolate $(9 \%)$ was detected and belonged to O26 serogroup. In poultry litter samples, $6(18 \%)$ isolates were determined as $\mathrm{O} 8$ serogroup. In ground beef meat samples, none of the EHEC serogroups was detected.

Thirty-five isolates belonged to E. coli $\mathrm{O} 157$ serogroup, 19 of them were O157:H7. However, O157:H7 was not detected in any of the samples obtained from animals or ground beef meat. In human samples, one $\mathrm{O} 157$ serotype was detected. None of the 44 human E. coli isolates carried sxt 1 or sxt 2 genes. In cattle samples, seven isolates were found to be $\mathrm{O} 157$ serotype, none of which carried the stx 1 or stx 2 genes. In poultry litter, six isolates were found to be $\mathrm{O} 157$ serotype, with no stx 1 and stx 2 genes. In sheep samples, six isolates were found to be O157 serotype, two of which carried the stx 1 gene. In goat samples, eight isolates were found to be O157 serotype, one of which carried the stx 1 gene. In ground beef meat samples, seven isolates were found to be $\mathrm{O} 157$ serotype, one of which carried the stx2 gene.

\section{Antimicrobial sensitivity patterns}

EHEC isolates showed high phenotypic resistance patterns against AX, CN, CL, and doxycycline. Thirtytwo (56\%) of the EHEC isolates showed 100\% resistance to at least two beta-lactams antibiotics, 24 (75\%) of which were determined as ESBL producers. Only 14 isolates of the ESBL producers expressed the $b l a_{S H V}$ gene, 19 isolates expressed the $b l a_{T E M}$ gene, 4 expressed both genes, and none carried the $O X A-1$ gene.

\section{PFGE}

PFGE analysis revealed two clusters containing isolates from cattle fecal samples and ground beef meat (Figure-1). The isolates within these clusters are closely related and can be considered identical. Each of the other clusters in the dendrogram contains only two isolates. There are two clusters of goat fecal samples, one cluster of sheep fecal samples and one cluster of ground beef meat samples that did not show any correlation with other ground beef meat cluster and cattle fecal samples cluster. The isolates from human fecal samples are not related to any other tested isolates.

\section{Discussion}

The present study reports the molecular characteristics of EHEC isolates from human and animal sources in Jordan. In this study, a total of $194 \mathrm{E}$. coli isolates were cultured from human $(44 \%)$, cattle (46\%), sheep (74\%), goats (54\%) fecal samples, poultry litter (39\%), and ground beef meat (50\%) samples. These results are similar to previously reported findings in various parts of the world [20,21]. High percentages $(29 \%)$ of $E$. coli isolates in this study were classified as EHEC in various sample sources $(20 \%$ of human samples, $17 \%$ of cattle samples, $46 \%$ of sheep samples, $47 \%$ of goat samples, $31 \%$ of poultry samples, and $35 \%$ of ground beef meat samples). These findings are higher than the results reported in Iran and the USA, in which EHEC were only recovered from $7.6 \%$ and $9 \%$ of broiler chickens' samples and cattle fecal samples, respectively [22,23].

In the present study, the frequency of $E$. coli $O 157$ serotypes varied according to the sample source. The incidence of $E$. coli $O 157$ was highest in sheep samples $(30.7 \%)$ and lowest in human samples $(2.3 \%)$. Similarly, the incidence of $O 157$ in Germany, Ghana, Iran, and Iraq among sheep, cattle, ground beef meat, and goats was $21 \%, 12.7 \%, 8.2 \%$, and $25 \%$, respectively [21-26].

Table-2: Serotypes and virulence genes in enterohemorrhagic Escherichia coli isolated from fecal samples of humans, animals, poultry litter, and ground beef meat.

\begin{tabular}{|c|c|c|c|c|c|c|c|c|}
\hline Sample source $(n)$ & Number of isolates (\%) & H7 & 0157 & 0157:H7 & 0157:H & Stx1 & Stx2 & Non-0157 \\
\hline Human (100) & $44(44)$ & $8(18.2)$ & $1(2.3)$ & $0(0)$ & $1(2.3)$ & $0(0)$ & $0(0)$ & $8(18.2)$ \\
\hline Cattle $(100)$ & $46(46)$ & $15(32.6)$ & $7(15)$ & $4(9)$ & $3(6)$ & $0(0)$ & $0(0)$ & $1(2)$ \\
\hline Broilers (100) & 39 (39) & $17(43.6)$ & $6(15)$ & $2(5)$ & $4(10)$ & $0(0)$ & $0(0)$ & $6(15)$ \\
\hline Sheep (35) & $26(74.3)$ & $8(30.7)$ & $6(31)$ & $3(11)$ & $3(11)$ & $2(8)$ & $0(0)$ & $6(23)$ \\
\hline Goats (35) & $19(54.3)$ & $4(21)$ & $8(21)$ & $4(21)$ & $4(21)$ & $1(5)$ & $0(0)$ & $1(5)$ \\
\hline Beef meat (40) & $20(50)$ & $13(65)$ & $7(35)$ & $6(30)$ & $1(5)$ & $0(0)$ & $1(5)$ & $0(0)$ \\
\hline Total (410) & $194(47.3)$ & $65(33.5)$ & $35(18)$ & $19(10)$ & $16(8)$ & $3(1.5)$ & $1(0.5)$ & $22(11)$ \\
\hline
\end{tabular}




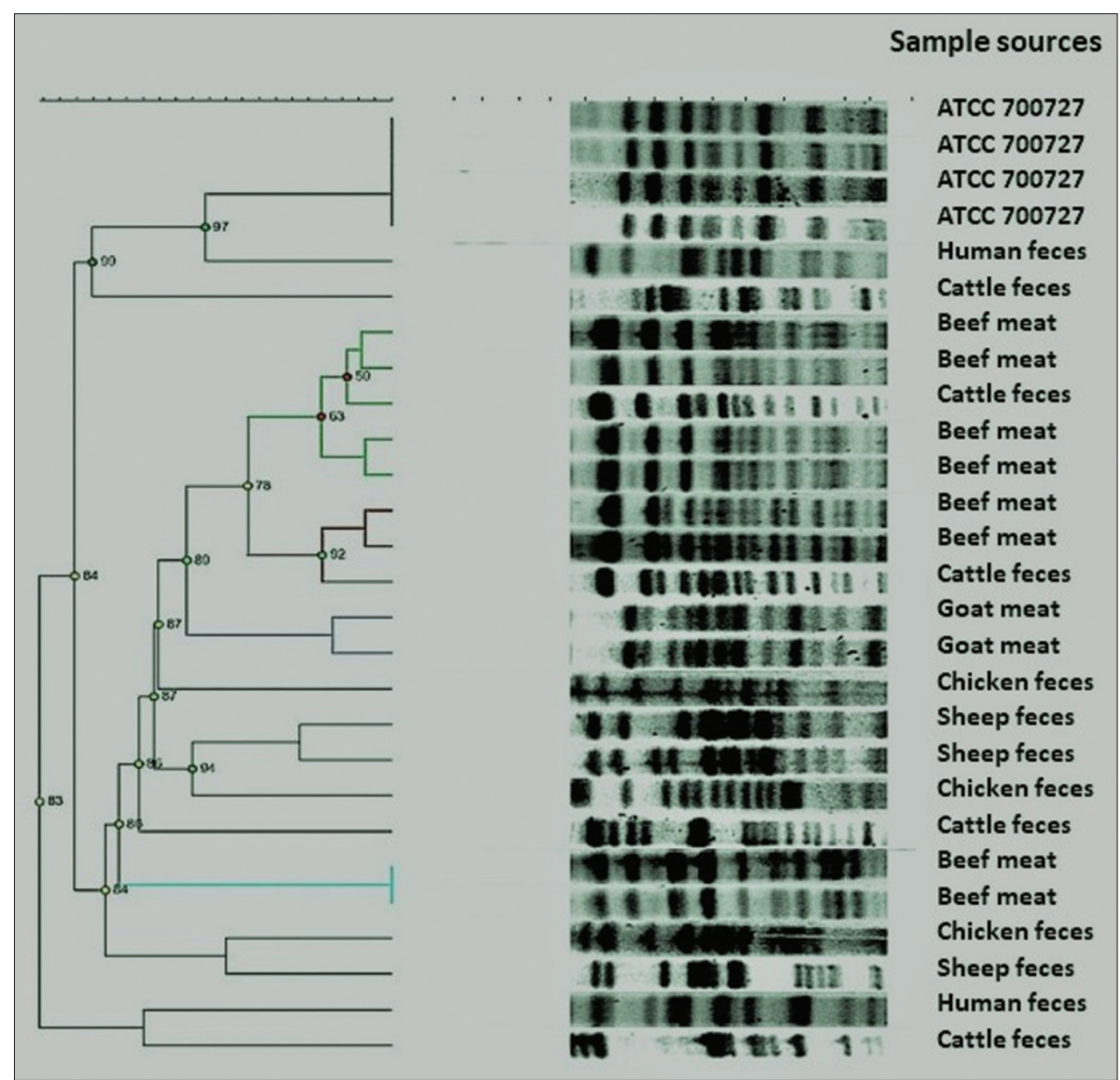

Figure-1: Dendrogram image showing the relatedness of pulsed-field gel electrophoresis patterns for Escherichia coli isolates from fecal samples of human and animals, poultry litter, and ground beef samples.

The occurrence of stxl in the current study was different from the Norwegian study which showed that sxt1 of EHEC non-O157 strain (O26) was detected in sheep fecal samples at a rate of $17.9 \%$ [27]. In this study, all isolates that carried the stxl gene were $\mathrm{O} 26$, and this finding is similar to that found in Australia [28]. On the other hand, the $s t x 2$ gene was detected in only one EHEC isolate $(5 \%)$ from beef ground meat. These results are different from previously reported data that showed $28 \%$ of 14 EHEC isolates carried stx2 [24]. In another study, $61 \%$ of non-O157 EHEC isolated from sheep and goats carried the stxl gene, $21 \%$ carried the stx 2 gene, and $18 \%$ carried both genes [29].

PFGE analysis of $E$. coli isolates from human, animal, and ground beef meat samples in this study revealed different clusters. These results showed high similarity (92\%) among isolates from ground beef meat and those from cattle fecal samples, which suggest a cross-contamination during processing. In addition, the isolates from beef meat were classified as O157:H7 serotype and those of cattle fecal samples were O157:NM. These results suggest a close genetic relationship between the isolates of EHEC O157 from ground beef meat and cattle origin. However, the results showed no relatedness between isolates from animal origin and human origin. These results are in agreement with the previously reported findings, which suggest no transmission of $E$. coli between animals and humans [30].

\section{Conclusion}

The results of this study indicate widespread ESBL EHEC among humans, animals, and ground beef meat samples. These results represent an important alarm that requires the implementation of appropriate preventative measures by both human and animal health sectors to prevent cross-transmission of this important foodborne pathogen.

\section{Authors' Contributions}

YHT and SNE: Conceived, designed, and supervised the study. ZBI: Analyzed the data and edited the final manuscript. AAA: Collected the samples, performed laboratory analysis, and wrote the manuscript. All authors read and approved the final manuscript.

\section{Acknowledgments}

This study was funded by the Deanship of Research at Jordan University of Science and Technology, Jordan (Project/Grant no. \# 2014/0163).

\section{Competing Interests}

The authors declare that they have no competing interests. 


\section{Publisher's Note}

Veterinary World remains neutral with regard to jurisdictional claims in published institutional affiliation.

\section{References}

1. Kaper, J.B., Nataro, J.P. and Mobley, H.L. (2004) Pathogenic Escherichia coli. Nat. Rev. Microbiol., 2(2): 123-140.

2. Gomes, T.A., Elias, W.P., Scaletsky, I.C., Guth, B.E., Rodrigues, J.F., Piazza, R.M., Ferreira, L.C. and Martinez, M.B. (2016) Diarrheagenic Escherichia coli. Braz. J. Microbiol., 47(1): 3-30.

3. Jenssen, G.R., Vold, L., Hovland, E., Bangstad, H.J., Nygård, K. and Bjerre, A. (2016) Clinical features, therapeutic interventions and long-term aspects of hemolytic-uremic syndrome in Norwegian children: A nationwide retrospective study from 1999-2008. BMC Infect. Dis., 16: 285.

4. Gardette, M., Hello, S.L., Mariani-Kurkdjian, P., Fabre, L., Gravey, F., Garrivier, A., Loukiadis, E. and Jubelin, G. (2019) Identification and prevalence of in vivo-induced genes in enterohemorrhagic Escherichia coli. Virulence, 10(1): 180-193.

5. Beauvais, W., Gart, E.V., Bean, M., Blanco, A., Wilsey, J., McWhinney, K., Bryan, L., Krath, M., Yang, C.Y., Alvarez, D.M., Paudyal, S., Bryan, K., Stewart, S., Cook, P.W., Lahodny, G., Baumgarten, K., Gautam, R., Nightingale, K., Lawhon, S.D., Pinedo, P. and Ivanek, R. (2018) The prevalence of Escherichia coli O157: H7 fecal shedding in feedlot pens is affected by the water-to-cattle ratio: A randomized controlled trial. PLoS One, 13(2): e0192149.

6. Bolukaoto, J.Y., Kock, M.M., Strydom, K.A., Mbelle, N.M. and Ehlers, M.M. (2019) Molecular characteristics and genotypic diversity of enterohemorrhagic Escherichia coli O157: H7 isolates in Gauteng region, South Africa. Sci. Total Environ., 692: 297-304.

7. Awad, W.S., El-Sayed, A.A., Mohammed, F.F., Bakry, N.M., Abdou, N.E.M. and Kamel, M.S. (2020) Molecular characterization of pathogenic Escherichia coli isolated from diarrheic and in-contact cattle and buffalo calves. Trop. Anim. Health Prod., 52(6): 3173-3185.

8. Kamel, M., El-Hassan, D.G.A. and El-Sayed, A. (2015) Epidemiological studies on Escherichia coli O157: H7 in Egyptian sheep. Trop. Anim. Health Prod., 47(6): 1161-1167.

9. Elbayoumi, Z.H., Shawish, R.R., Hamada, M. and Esmail, H.R. (2018) Molecular characterization of Escherichia coli isolated from poultry meat and its products. Alex. J. Vet. Sci., 56(2): 39-47.

10. Otero, V., Rodríguez-Calleja, J.M., Otero, A., GarcíaLópez, M.L. and Santos, J.A. (2013) Genetic characterization of atypical enteropathogenic Escherichia coli isolates from ewes' milk, sheep farm environments, and human by multilocus sequence typing and pulsed-field gel electrophoresis. Appl. Environ. Microbiol., 79(19): 5864-5869.

11. Martins, F.H., Guth, B.E., Piazza, R.M., Elias, W.P., Leão, S.C., Marzoa, J., Dahbi, G., Mora, A., Blanco, M., Blanco, J. and Pelayo, J.S. (2016) Lambs are an important source of atypical enteropathogenic Escherichia coli in Southern Brazil. Vet. Microbiol., 196: 72-77.

12. Tonu, N.S., Sufian, M.A., Sarker, S., Kamal, M.M., Rahman, M.H. and Hossain, M.M. (2011) Pathological study on colibacillosis in chickens and detection of Escherichia coli by PCR. Bangladesh J. Vet. Med., 9(1): 17-25.

13. Yee, W., Abdul-Kadir, R., Lee, L.M., Koh, B., Lee, Y.S. and Chan, H.Y. (2018) A simple and inexpensive physical lysis method for DNA and RNA extraction from freshwater microalgae. 3 Biotech., 8(8): 354

14. Wang, R.F., Cao, W.W. and Cerniglia, C.E. (1977) A universal protocol for PCR detection of 13 species of foodborne pathogens in foods. J. Appl. Microbiol., 83(6): 727-736.

15. Campbell, G.R., Prosser, J., Glover, A. and Killham, K. (2001) Detection of Escherichia coli O157: H7 in soil and water using multiplex PCR. J. Appl. Microbiol., 91(6): 1004-1010.

16. Bai, J., Paddock, Z.D., Shi, X., Li, S., An, B. and Nagaraja, T.G. (2012) Applicability of a multiplex PCR to detect the seven major shiga toxin-producing Escherichia coli based on genes that code for serogroup-specific $\mathrm{O}$-antigens and major virulence factors in cattle feces. Foodborne Pathog. Dis., 9(6): 541-548.

17. Swedan, S. and Abu Alrub, H. (2019) Antimicrobial resistance, virulence factors, and pathotypes of Escherichia coli isolated from drinking water sources in Jordan. Pathogens, 8(2): 86 .

18. Dallenne, C., Da Costa, A., Decre, D., Favier, C. and Arlet, G. (2010) Development of a set of multiplex PCR assays for the detection of genes encoding important beta-lactamases in Enterobacteriaceae. J. Antimicrob. Chemother., 65(3): 490-495.

19. Kalender, H. and Kilic, A. (2016) Molecular characterisation of shiga toxin-producing Escherichia coli O157: H7 isolates from cattle in eastern Turkey. Vet. Med., 61(12): 663-668.

20. Soltani, M., Peighambari, S.M., Badouei, A.M. and Sadrzadeh, A. (2012) Molecular typing of avian Escherichia coli isolates by enterobacterial repetitive intergenic consensus sequence polymerase chain reaction (ERIC-PCR). Iran. J. Vet. Med., 6(3): 43-148.

21. Saba, C., Eric, Y. and Adzitey, F. (2015) Prevalence of Escherichia coli and Shiga toxin-producing Escherichia coli in cattle faeces and raw cow milk sold in the tamale metropolis, Ghana. J. Dairy Vet. Anim. Res., 2(5): 00052.

22. Alam, M.J. and Zurek, L. (2006) Seasonal prevalence of Escherichia coli 0157: H7 in beef cattle feces. J. Food Prot., 69(12): 3018-3020.

23. Karimi, V., Zahraei, S., Sadegh, M. and Jaafarnejad, S. (2011) The relation of water contamination and colibacillosis occurrence in poultry farms in Qom province of Iran. Iran. J. Vet. Res., 12(2): 133-135.

24. Chieuh, L., Liu, F. and Shih, D. (2002) Prevalence of Shiga toxin-producing Escherichia coli in feces and raw milk of domestic cattle and sheep. J. Food Drug Anal., 10(1): 39-46.

25. Rahimi, E., Kazemeini, H.R. and Salajegheh, M. (2012) Escherichia coli O157: H7/NM prevalence in raw beef, camel, sheep, goat, and water buffalo meat in Fars and Khuzestan provinces, Iran. Vet. Res. Forum, 3(1): 15-17.

26. Hamzah, M., Hussein, M. and Khalef, M. (2014) Isolation of Escherichia coli 0157: H7 strain from fecal samples of zoo animal. Sci. World J., 2013: 843968.

27. Sekse, C., Sunde, M., Lindstedt, B.A., Hopp, P., Bruheim, T., Cudjoe, K.S., Kvitle, B. and Urdahl, A.M. (2011) Potentially human-pathogenic Escherichia coli O26 in Norwegian sheep flocks. Appl. Environ. Microbiol., 77(14): 4949-4958.

28. Caprioli, A., Morabito, S., Brugere, H. and Oswald, E. (2005) Enterohaemorrhagic Escherichia coli: Emerging issues on virulence and modes of transmission. Vet. Res., 36(3): 289-311.

29. Son, I., Binet, R., Maounounen-Laasri, A., Lin, A., Hammack, T.S. and Kase, J.A. (2014) Detection of five Shiga toxin-producing Escherichia coli genes with multiplex PCR. Food Microbiol., 40: 31-40.

30. Kalin, R., Ongor, H. and Cetinkaya, B. (2012) Isolation and molecular characterization of Escherichia coli $\mathrm{O} 157$ from broiler and human samples. Foodborne Pathog. Dis., 9(4): 313-318. 